\title{
Use of maltodextrin and a prebiotic in the feed of weaned piglets
}

\section{Uso de maltodextrina e prebiótico em rações de leitões desmamados}

\author{
Mayara Rodrigues Pivetta ${ }^{1 *}$; Dirlei Antonio Berto ${ }^{2}$; \\ Alessandro Borges Amorim³; Mayra Anton Dib Saleh; \\ Daniela Felipe Pinheiro5; Maria de Lourdes Mendes Vicentini Paulino ${ }^{6}$; \\ José Paes de Almeida Nogueira Pinto ${ }^{7}$; Heraldo Cesar Gonçalves ${ }^{2}$
}

\begin{abstract}
Two experiments were conducted to evaluate the effect of replacing lactose with maltodextrin and adding fructooligosaccharides (FOSs) to the feed of weaned piglets. The first experiment was conducted using a randomized block design with a $2 \times 2$ factorial arrangement $(2$ sources of carbohydrates: maltodextrin and lactose in the pre-starter feed and with or without the use of $0.3 \%$ FOS in the prestarter and starter feeds) with 7 repetitions in 3 animals. Performance and hematological parameters were evaluated. The second experiment was conducted using a randomized block design with a $2 \times 2 \times$ $2+1$ factorial arrangement ( 2 sources of carbohydrates: maltodextrin and lactose and with or without the use of $0.3 \%$ FOS; 2 slaughter dates: 7 and $14 \mathrm{~d}$ post-weaning; and slaughter on the day of weaning) with 8 repetitions in 1 animal. The following parameters were evaluated: $\mathrm{pH}$ and relative weight of digestive organs, enzyme activity, and microbial population. In the initial phase, maltodextrin did not compromise performance and could replace lactose with economic benefits; however, it does reduce intake of the pre-starter I feed. Maltodextrin has a prebiotic effect because it reduces the total coliform and $E$. coli populations in the cecum and reduces the $\mathrm{pH}$ of the rectal contents. The use of FOSs is not justified, regardless of whether lactose or maltodextrin is added to the feed.
\end{abstract}

Key words: Fructooligosaccharides, lactose, enzymes, microbiota, swine

\section{Resumo}

Dois experimentos foram conduzidos com o objetivo de avaliar o efeito da substituição da lactose pela maltodextrina e da adição de frutoligossacarídeos (FOS) nas rações de leitões desmamados. O primeiro experimento apresentou delineamento de blocos casualizados com arranjo fatorial $2 \times 2$ (duas fontes de carboidratos: maltodextrina e lactose na ração pré-inicial; com ou sem uso de $0,3 \%$ de

\footnotetext{
${ }^{1}$ Zootecnista, Discente do Curso de Doutorado em Zootecnia, Dept ${ }^{\circ}$ de Melhoramento e Nutrição Animal, Faculdade de Medicina Veterinária e Zootecnia, Universidade Estadual Paulista "Julio de Mesquita Filho", UNESP, Botucatu, SP, Brasil. E-mail: mayara_rodriguez@yahoo.com.br

2 Profs. Assistente Drs., Faculdade de Medicina Veterinária e Zootecnia, Dept ${ }^{\circ}$ de Produção Animal, UNESP, Botucatu, SP, Brasil. E-mail: dirleiberto@fmvz.unesp.br; heraldo@fmvz.unesp.br

3 Zootecnista, Dr. em Zootecnia, Faculdade de Medicina Veterinária e Zootecnia, Dept ${ }^{\circ}$ de Produção Animal, UNESP, Botucatu, SP, Brasil. E-mail: alessandrozoo@gmail.com

${ }^{4}$ Zootecnista, Discente do Curso de Doutorado em Zootecnia, Faculdade de Medicina Veterinária e Zootecnia, Dept ${ }^{\circ}$ de Produção Animal, UNESP, Botucatu, SP, Brasil. E-mail: dib_saleh@yahoo.com.br

${ }^{5}$ Zootecnista, Pós-Doutora com especialidade em Fisiologia da Digestão, Instituo de Biociências, Dept ${ }^{\circ}$ de Fisiologia, UNESP, Botucatu, SP, Brasil. E-mail: danizootec22@yahoo.com.br

${ }^{6}$ Prof $^{a}$ Dr $^{a}$ Assistente, Instituto de Biociências, Dept ${ }^{\circ}$ de Fisiologia Animal, UNESP, Botucatu, SP, Brasil. E-mail: mlvpauli@ibb. unesp.br

7 Profs. Assistentes Drs., Faculdade de Medicina Veterinária e Zootecnia, Dept ${ }^{\circ}$ de Higiene Veterinária e Saúde Pública, UNESP, Botucatu, SP, Brasil. E-mail: josepaes@fmvz.unesp.br

* Author for correspondence
} 
frutoligossacarídeo, nas rações pré-inicial e inicial) com sete repetições de três animais. Foram avaliados o desempenho e parâmetros hematológicos. No segundo experimento foi empregado o delineamento de blocos casualizados em arranjo fatorial $2 \times 2 \times 2+1$ (duas fontes de carboidratos: maltodextrina e lactose; com ou sem uso de $0,3 \%$ de frutoligossacarídeo; duas épocas de abate: sete e quatorze dias pós-desmame; e abate no dia do desmame) com oito repetições de um animal. Foram avaliados o pH e peso relativo de órgãos do sistema digestório, atividade enzimática e população microbiana. Na fase inicial a maltodextrina não compromete o desempenho e pode substituir com vantagem econômica a lactose, contudo, reduz a ingestão da ração pré-inicial I. A maltodextrina possui efeito prebiótico, pois reduz a população de coliformes totais e de E. coli no ceco e o pH do conteúdo do reto. $\mathrm{O}$ uso de frutoligossacarídeo não se justifica independente de se usar lactose ou maltodextrina nas rações.

Palavras-chave: Frutoligossacarídeos, lactose, enzimas, microbiota, suíno

\section{Introduction}

Piglets face significant challenges in the first few days after weaning. From a nutritional point of view, one of the most relevant challenges is the transition from a milk-based liquid diet to a solid diet, which is predominantly composed of plant-derived ingredients. Therefore, the gastrointestinal system of newly weaned piglets must readjust to changes in the physical and chemical properties of their food, and their feeding pattern must be adjusted to enable them to digest and absorb nutrients and maintain an acceptable level of growth (JENSEN; JENSEN; JAKOBSEN, 1997).

Because the digestive system of piglets is adapted to milk components, post-weaning diets have been formulated with lactose-rich ingredients that stimulate the intake of food, help diet transitions (BERROCOSO et al., 2012), and increase digestibility (O'DOHERTY; NOLAN; MCCARTHY, 2005), thereby mitigating the decrease in post-weaning performance. However, this results in an increase in the feeding costs, which, in turn, increases the total cost of pig production (SOARES et al., 2000).

Because of variations in the price and availability of dairy products, it is important to study the use of alternative sources of carbohydrates to replace lactose. Research has shown that it is possible to use hydrolyzed corn starch as a replacement for lactose in diets without adversely affecting the performance of piglets (MAHAN; NEWTON, 1993; OLIVER et al., 2002).
Maltodextrin, a carbohydrate derived from the partial hydrolysis of starch and with a dextrose equivalent (DE) of less than 20, has been shown to be effective in partially (SILVA et al., 2008) or totally (AUGUSTO et al., 2011) replacing lactose in the feed of weaned piglets. Considering that post-weaning lactase activity in pigs is higher than that of maltase (KIDDER; MANNERS, 1980), maltodextrin might induce the synthesis of maltase through modulation of enzyme activity exerted by the substrate. Moreover, maltodextrin might have a prebiotic effect. Nemcová et al. (2007) observed a reduction in E. coli counts in the jejunum of piglets fed diets containing Lactobacillus plantarum + maltodextrin + fructooligosaccharides (FOSs), as well as in animals fed diets containing only $L$. plantarum + maltodextrin.

Prebiotics such as FOSs are non-digestible substances that beneficially affect the host by selectively stimulating growth or activity of a limited number of beneficial bacteria of the intestinal microbiota (ROBERFROID, 2007). Prebiotics might also affect the immune system as a direct or indirect result of the change in the composition and fermentation profiles of the intestinal microbiota (ROBERFROID et al., 2010). In addition, FOSs contribute to the increase in maltase activity, as shown by Chotikatum, Kramomthong and Angkanaporn (2009) in broiler chickens.

The aim of the present study was to assess the effects of replacing lactose with maltodextrin and adding FOSs to the pre-starter and starter feeds on 
the performance, hematological parameters, $\mathrm{pH}$ of the digesta, relative weight of the digestive-tract organs, microbial population in the cecum, lactase and maltase activities in the jejunum microbiota, and amylase activity in the pancreas of weaned piglets.

\section{Materials and Methods}

Two experiments were conducted in the nursery facilities of the Intensive Pig Farming department of the Faculty of Veterinary Medicine and Zootechnics of the Universidade Estadual Paulista (UNESP), Botucatu Campus.

We used 156 commercial crossbred piglets that were weaned at a mean age of $21 \mathrm{~d}$ and with an initial mean weight of $6.28 \pm 0.39 \mathrm{~kg}$ in the first experiment and $6.28 \pm 0.29 \mathrm{~kg}$ in the second experiment. The piglets were housed in suspended metal nursery pens with slatted floors, measuring $1.75 \mathrm{~m}^{2}$ and equipped with nipple drinkers, feeders, and a hood with electrical resistance heating.

\section{Experiment I}

Experiment I was conducted using a randomized block design with a $2 \times 2$ factorial arrangement $(2$ sources of carbohydrates: maltodextrin and lactose, with or without the use of $0.3 \%$ FOS in pre-starter I and II and starter diets), with 7 repetitions and 3 animals per experimental unit (84 piglets: 48 males and 36 females). The animals were divided into blocks based on their initial weight and sex.

The experiment took place over $38 \mathrm{~d}$, during which the animals received 3 types of diet ad libitum, in accordance with the phased feeding system: prestarter I diet in the first $17 \mathrm{~d}$, pre-starter II diet in the following $12 \mathrm{~d}$, and starter diet in the last $9 \mathrm{~d}$ (Table 1). To determine any residual effects of treatments in the first $29 \mathrm{~d}$ and in the last $9 \mathrm{~d}$ of the experimental period, the animals were fed diets without sources of carbohydrates; however, they were still fed diets with or without the prebiotic $(0.3 \%$ FOS). The maltodextrin used was between 17.0 and 19.9 DE. All feeds were formulated according to the nutritional recommendations proposed by Rostagno et al. (2005).

We assessed the animals' daily feed intake, daily weight gain, and food conversion during 3 periods (0-17, 0-29, and 0-38 d post-weaning. The feed intake was calculated based on the quantity of feed supplied during a given period and weighed leftovers. The weight gain was calculated by weighing the animals at the beginning of the experiment and at days 17,29 , and 38 of the initial phase.

Blood was collected through the vena cava from all animals on day 21 of the experimental unit. The samples were collected in EDTA tubes, labeled, stored in a Styrofoam box with ice, and sent to the medical laboratory in Botucatu, São Paulo.

Erythrocyte and leukocyte counts; red blood cell (RBC) indices, namely, mean corpuscular volume (MCV), mean corpuscular hemoglobin (HCM), and mean corpuscular hemoglobin concentration (MCHC); and platelet counts were performed using a Maxcom MC-6200 VET Auto Hematology Analyzer (Shenzheng Maxcom Electronic Ltd., Shenzhen, China). The percentage of hematocrit was calculated from the MCV and RBC values that were measured by impedance. The concentration of hemoglobin was measured by spectrophotometry. The concentration of total plasma protein was measured by refractometry following heat coagulation.

Data were subjected to analysis of variance (ANOVA) for factorial arrangements and the means were compared using the $\mathrm{F}$ test at a significance level of 5\% using the SAEG (2009). 
Table 1. Composition (\%) and nutritional levels of the pre-starter and starter diets.

\begin{tabular}{|c|c|c|c|}
\hline \multirow{2}{*}{ Ingredients $(\%)$} & Pre-starter I & Pre-starter II & Starter \\
\hline & $0-17 \mathrm{~d}$ & $18-29 \mathrm{~d}$ & $30-38 \mathrm{~d}$ \\
\hline Corn, Grain & 52.650 & 56.815 & 69.875 \\
\hline Soya, Bran & 20.000 & 25.800 & 26.000 \\
\hline Blood plasma & 4.000 & 2.000 & - \\
\hline Blood cells & 1.500 & 1.300 & - \\
\hline Alcohol distillery yeast & 1.300 & - & - \\
\hline Sugar & 2.000 & 2.000 & - \\
\hline Soya oil & 2.000 & 2.200 & 0.400 \\
\hline Lactose or Maltodextrin & 1.000 & 6.000 & - \\
\hline Limestone & 0.680 & 0.680 & 0,600 \\
\hline Dicalcium phosphate & 2.000 & 1.900 & 1.600 \\
\hline BHT & 0.015 & 0.015 & 0.015 \\
\hline Sodium chloride & 0.260 & 0.300 & 0.320 \\
\hline L-Lysine HCL & 0.520 & 0.400 & 0.290 \\
\hline DL-Methionine & 0.150 & 0.100 & 0.020 \\
\hline L-Threonine & 0.220 & 0.160 & 0.070 \\
\hline L-Tryptophan & 0.035 & - & - \\
\hline Zinc Oxide & 0.340 & - & - \\
\hline Choline chloride & 0.065 & 0.065 & 0.060 \\
\hline Sweetener ${ }^{1}$ & 0.015 & 0.015 & - \\
\hline Vitamin premix ${ }^{2}$ & 0.150 & 0.150 & 0.150 \\
\hline Mineral premix ${ }^{3}$ & 0.100 & 0.100 & 0.100 \\
\hline Antibiotic $^{4}$ & - & - & 0.200 \\
\hline FOS $^{5}$ or inert ${ }^{6}$ & 0.300 & 0.300 & 0.300 \\
\hline \multicolumn{4}{|l|}{ Calculated nutritional levels } \\
\hline Metabolizable energy $\left(\mathrm{kcal} \cdot \mathrm{kg}^{-1}\right)$ & $3,350.000$ & $3,350.000$ & $3,230.000$ \\
\hline Crude Protein (\%) & 19.500 & 19.500 & 18.000 \\
\hline Digestible Lysine (\%) & 1.430 & 1.330 & 1,040 \\
\hline Digestible Methionine (\%) & 0.420 & 0.370 & 0.280 \\
\hline Digestible Threonine (\%) & 0.900 & 0.840 & 0.670 \\
\hline Digestible Tryptophan (\%) & 0.250 & 0.220 & 0.190 \\
\hline Calcium $(\%)$ & 0.840 & 0.830 & 0.730 \\
\hline Available Phosphorus (\%) & 0.470 & 0.460 & 0.400 \\
\hline Lactose or Maltodextrin $(\%)$ & 12.000 & 6.000 & - \\
\hline
\end{tabular}

${ }^{1}$ Sucram $150{ }^{\circledR}$. ${ }^{2}$ Vitamin premix provides the following quantities per $\mathrm{kg}$ of feed: $9000 \mathrm{IU}$ vit. A; $2250 \mathrm{IU}$ vit. D3; $22.5 \mathrm{mg}$ vit. E; $22.5 \mathrm{mg}$ vit. $\mathrm{K} 3 ; 2.03 \mathrm{mg}$ vit. B1; $6 \mathrm{mg}$ vit. B2; $3 \mathrm{mg}$ vit. B6; $30 \mu \mathrm{g}$ vit. B12; $0.9 \mathrm{mg}$ folic acid; $14.03 \mathrm{mg}$ pantothenic acid; $30 \mathrm{mg}$ niacin; $0.12 \mathrm{mg}$ biotin; $400 \mathrm{mg}$ choline. ${ }^{3}$ Mineral premix provides the following quantities per $\mathrm{kg}$ of feed: $100 \mathrm{mg} \mathrm{Fe} ; 10 \mathrm{mg} \mathrm{Cu}$; $100 \mathrm{mg}$ Zn; 40 mg Mn; $1 \mathrm{mg}$ Co; $1.5 \mathrm{mg} \mathrm{I.}{ }^{4}$ Taylan S100 ${ }^{\circledR} .{ }^{5}$ Fructooligosaccharide. ${ }^{6} \mathrm{Caulim}$.

Source: Elaboration of the authors.

\section{Experiment II}

Experiment II was conducted using a randomized block design with a $2 \times 2 \times 2+1$ factorial arrangement: 2 sources of carbohydrates (maltodextrin and lactose), with or without $0.3 \%$ FOSs; 2 slaughter dates ( 7 and 14 d post-weaning); and slaughter on the day of weaning as an additional treatment, with 8 repetitions and 1 animal per unit. The animals were divided into blocks based on their initial weight and sex.

During the experiment, the animals were fed the pre-starter diet I ad libitum, which was formulated in accordance with the nutritional recommendations proposed by Rostagno et al. (2005) (Table 1). 
Eight piglets were killed by electrical stunning on the day of weaning, 32 on day 7, and 32 on day 14 of the experiment (72 animals: 36 males and 36 females) to assess the following parameters: weight of empty stomach, small intestine, cecum, and large intestine; $\mathrm{pH}$ of the stomach, jejunum, colon, and rectum; total coliform, E. coli and Lactobacillus spp. populations in the cecum; lactase and maltase activities in the jejunal mucosa; and amylase activity in the pancreas.

A longitudinal incision was performed in the animals' abdominal cavity to remove the digestive organs (stomach, small intestine, cecum, and large intestine). The organs were washed to remove the digestive contents and placed on paper towels to remove excess liquid. They were then weighed to determine the organs' absolute weight. The organs' relative weight was calculated based on the piglets' live weight.

The $\mathrm{pH}$ of the contents of the stomach, jejunum, colon, and rectum was measured immediately after the piglets were slaughtered using an mPA $210 \mathrm{P}$ portable $\mathrm{pH}$ meter.

Total coliform and E. coli was counted by collecting $10 \mathrm{~g}$ of the cecal contents, adding $90 \mathrm{~mL}$ of $0.85 \%$ saline solution, and homogenizing in a "stomacher" for $2 \mathrm{~min}$, obtaining a 10-1 dilution. Serial decimal dilutions were prepared from this sample by transferring $1 \mathrm{~mL}$ of each dilution onto ECTM Petrifilm plates that were incubated at $35^{\circ} \mathrm{C}$ for $24 \mathrm{~h}$ (AOAC, 2000). The Lactobacillus spp count was performed from serial decimal dilutions, as described for counting E. coli; $0.1 \mathrm{~mL}$ was transferred onto Petri dishes with de ManRogosa-Sharpe media (surface streaking) that were incubated for $5 \mathrm{~d}$ at $30^{\circ} \mathrm{C}$ and $5 \% \mathrm{CO}_{2}$ in an incubator (DOWNES; ITO, 2001). Microbial population data were expressed in $\log 10$.

The animals' small intestines (segments of approximately $10 \mathrm{~cm}$ of the middle portion of the jejunum) and pancreas were removed, washed in saline solution, weighed, and frozen in liquid nitrogen for the analysis of maltase and lactase activity in the intestinal mucosa and amylase activity in the pancreas. To determine the activity of the intestinal enzymes, the samples were thawed and the mucosa was scraped and homogenized after the addition of 4 parts distilled water. Aliquots of the homogenized material were incubated with either lactose or maltose. Lactase and maltase activities were measured according to Dahlquist (1964) and were based on the amount of glucose produced during the reaction (glucose oxidase method, Laborlab, Brazil).

The pancreas was homogenized in a $50-\mathrm{mM}$ Tris-HCl buffer solution ( $\mathrm{pH} 8.0)$ at a ratio of 1:20. The pancreatic amylase activity was determined using iodometric titration.

Enzyme activity was expressed in specific and total activity. The specific activity was expressed in $\mathrm{u} \mathrm{g}^{-1}$ of mucosa, where $\mathrm{u}$ represents the hydrolysis of $1 \mu \mathrm{mol}$ disaccharide $\mathrm{min}^{-1}$ at $37^{\circ} \mathrm{C}$ (for disaccharidases) and the hydrolysis of $10 \mathrm{mg}$ starch in $30 \mathrm{~min}$ (for amylase). The total activity was calculated by multiplying the specific activity by the weight of the intestinal or pancreatic segment and dividing by the animal's live weight.

Data were subjected to ANOVA for factorial arrangements using SAEG (2009), and the following procedure was used to compare the means:

1. If in ANOVA the additional treatment (weaning) $\times$ factorial $(2 \times 2 \times 2)$ interaction did not have a significant effect, the means of the other sources of variation that had a significant effect were compared using the $\mathrm{F}$ test at a significance level of $5 \%$.

2. If the additional treatment $\times$ factorial interaction had a significant effect, the procedure described above was used for the means of sources of variation that had a significant effect and the Dunnett test (5\% significance level) was used to compare the means of the additional treatment to the means of the sources of variation that had a significant effect. 


\section{Results and Discussion}

\section{Experiment I}

The interaction between the sources of carbohydrates and FOSs was not significant $(\mathrm{P}>$ 0.05 ) for the performance variables. Between 0 and $17 \mathrm{~d}$ post-weaning, the piglets that received maltodextrin exhibited lower daily feed intake ( $\mathrm{P}$ $<0.05)$; therefore, they showed lower daily weight gain $(\mathrm{P}<0.05)$. The feed conversion of the sources of carbohydrates was similar $(\mathrm{P}>0.05)$ (Table 2).

Table 2. Mean values of daily feed intake (DFI), daily weight gain (DWG) and feed conversion (FC) of piglets as affected by sources of carbohydrates and use of prebiotic.

\begin{tabular}{|c|c|c|c|c|c|}
\hline \multirow{2}{*}{ Performance } & \multicolumn{2}{|c|}{ Carbohydrate } & \multicolumn{2}{|c|}{ Fructooligosaccharides } & \multirow[b]{2}{*}{ CV $(\%)$} \\
\hline & Maltodextrin & Lactose & With & Without & \\
\hline & \multicolumn{4}{|c|}{0 to 17 days after weaning } & \\
\hline DFI $(g)$ & $399 \mathrm{~b}$ & $446 \mathrm{a}$ & 409 & 436 & 11.55 \\
\hline DWG $(g)$ & $295 \mathrm{~b}$ & $333 \mathrm{a}$ & 307 & 321 & 12.70 \\
\hline \multirow[t]{2}{*}{$\mathrm{FC}$} & 1.36 & 1.34 & 1.34 & 1.36 & 4.82 \\
\hline & \multicolumn{4}{|c|}{0 to 29 days after weaning } & \\
\hline DFI $(g)$ & 578 & 604 & 582 & 600 & 8.19 \\
\hline DWG $(g)$ & 387 & 403 & 393 & 397 & 9.37 \\
\hline \multirow[t]{2}{*}{$\mathrm{FC}$} & 1.50 & 1.50 & 1.49 & 1.51 & 5.41 \\
\hline & \multicolumn{2}{|c|}{0 to 38 days after weaning } & & & \\
\hline DFI $(g)$ & 736 & 736 & 743 & 728 & 7.64 \\
\hline DWG (g) & 470 & 468 & 479 & 460 & 7.60 \\
\hline $\mathrm{FC}$ & 1.57 & 1.57 & 1.55 & 1.59 & 3.62 \\
\hline
\end{tabular}

Means in the same row with different letters are statistically different by $\mathrm{F}$ test $(\mathrm{P}<0.05)$; CV: Coefficient of variation.

Source: Elaboration of the authors.

A higher lactose-containing feed intake is related to its palatability enhancing effect (BERTOL; SANTOS FILHO; LUDKE, 2000). In feeders, the feed containing maltodextrin was characterized by the aggregation of particles that formed small lumps and adhered to the internal surface of the feeding nozzles; this resulted in the formation of a crust. Bhandari, Datta and Howes (1997) demonstrated that hygroscopicity and viscosity are lower in lactose than in maltose, one of the constituents of maltodextrin.

Some sensory additives that are added to the feeds of pregnant or lactating pigs might condition the piglets, through the amniotic fluid or milk, and feed that contains those additives may be provided during the post-weaning period, thus, inducing a high feed intake (LANGENDIJK; BOLHUIS; LAURENSSEN, 2007; OOSTINDJER et al.,
2010). Furthermore, piglets are able to distinguish the constituents of their diet, not only by their sensorial properties but also by their nutritional properties (CLOUARD et al., 2012). Therefore, piglets might have consumed more feed containing lactose (Table 2), because they were conditioned to this carbohydrate during the lactation period, even though the presence of lactose did not make the feed taste like milk.

The reduction in the intake of feed containing maltodextrin occurred in only the first $17 \mathrm{~d}$ of the experiment; during the remaining periods (0-29 d and $0-38 \mathrm{~d}$ post-weaning) the piglets were able to adjust and the type of carbohydrate did not affect ( $\mathrm{P}$ $>0.05$ ) the performance variables (Table 2).

The use of FOSs in the feed did not have a beneficial effect $(\mathrm{P}>0.05)$ on the performance of piglets in any of the periods (Table 2), which 
may be because of the low-challenge conditions to which the animals were exposed. Before the start of the experiment, the facilities were properly cleaned, disinfected, and subjected to fallowing for a minimum of $15 \mathrm{~d}$. Moreover, the pre-starter feeds contained zinc oxide, which is proven to be effective in reducing $E$. coli adhesion to the intestinal cells (SARGEANT et al., 2010), thereby reducing enteric problems in weaned piglets. Nemcová et al. (1999) andBomba etal.(2002) observed the beneficial effect of using FOSs in the diets of piglets on the intestinal microflora, which, according to Shim, Williams and Verstegen (2005), might induce an increase in feed intake because of a reduction in digestive disorders.
Moreover, the use of FOSs in feeds has been shown to improve piglets' performance, even under lowchallenge sanitary conditions (BUDIÑO; CASTRO JÚNIOR; OTSUK, 2010).

There was no significant interaction $(\mathrm{P}>0.05)$ between the source of carbohydrates and FOSs for any hematological parameter (Table 3). The platelet count was lower $(\mathrm{P}<0.05)$ when FOSs were present in the feed, which is not in accordance with the results of Visentini et al. (2008), who did not find an effect of including FOSs in feeds of weaned piglets on platelet count; however, these authors observed a large variation in the number of platelets among piglets, as was the case in the present experiment.

Table 3. Mean values of hematological parameter of piglets as affected by sources of carbohydrates and use of prebiotic, at 21 days after weaning.

\begin{tabular}{|c|c|c|c|c|c|}
\hline \multirow{2}{*}{ Hemograma } & \multicolumn{2}{|c|}{ Carbohydrate } & \multicolumn{2}{|c|}{ Fructooligosaccharides } & \multirow{2}{*}{ CV $(\%)$} \\
\hline & Maltodextrin & Lactose & With & Without & \\
\hline $\operatorname{RBC}\left(\times 10^{6} \mathrm{~mm}^{-3}\right)$ & 6.79 & 6.73 & 6.68 & 6.83 & 4.96 \\
\hline $\mathrm{Hb}\left(\mathrm{g} \mathrm{dl}^{-1}\right)$ & 12.85 & 12.92 & 12.89 & 12.89 & 4.84 \\
\hline $\mathrm{Ht}(\%)$ & 39.27 & 39.48 & 39.34 & 39.41 & 4.93 \\
\hline MCV (fL) & 58.18 & 58.78 & 59.16 & 57.8 & 3.82 \\
\hline MCH (pg) & 19.04 & 19.24 & 19.38 & 18.9 & 4.74 \\
\hline $\operatorname{MCHC}\left(\mathrm{g} \mathrm{dl}^{-1}\right)$ & 32.74 & 32.74 & 32.79 & 32.69 & 1.83 \\
\hline $\operatorname{WBC}\left(\mathrm{n}^{\mathrm{o}} \mu \mathrm{l}^{-3}\right)$ & 17048 & 16081 & 16567 & 16562 & 12.04 \\
\hline $\operatorname{PLT}\left(\mathrm{n}^{\mathrm{o}} \mu \mathrm{l}^{-3}\right)$ & 622298 & 570286 & $530250 \mathrm{~b}$ & $662333 \mathrm{a}$ & 20.40 \\
\hline $\operatorname{TPP}\left(\mathrm{g} \mathrm{dl}^{-1}\right)$ & $6.41 \mathrm{~b}$ & $6.56 \mathrm{a}$ & 6.48 & 6.49 & 2.78 \\
\hline
\end{tabular}

RBC: red blood cells; Hb: hemoglobin; Ht: hematocrit; MCV: mean corpuscular volume; MCH: mean corpuscular hemoglobin; MCHC: mean corpuscular hemoglobin concentration; WBC: leukocytes; PLT: platelets; TPP: total plasma protein; Means in the same row with different letters are statistically different by $\mathrm{F}$ test $(\mathrm{P}<0.05)$; $\mathrm{CV}$ : Coefficient of variation.

Source: Elaboration of the authors.

The total plasma protein concentration was higher $(\mathrm{P}<0.05)$ in piglets fed with lactosecontaining feeds (Table 3). Considering that the protein quantity and quality of diets containing maltodextrin and lactose were identical, this result is probably related to higher feed intake and, thus, higher protein intake by the animals that were fed a diet with lactose in the first $17 \mathrm{~d}$ of the experiment (Table 2).

Despite the differences observed in the number of platelets and in total plasma protein concentration, all the hematological parameters that were assessed were within the normal ranges for piglets (JAIN, 1993).

\section{Experiment II}

The interactions were not significant $(\mathrm{P}>0.05)$ for the $\mathrm{pH}$ of the gastrointestinal tract. The $\mathrm{pH}$ of the stomach of the animals slaughtered at weaning was lower $(\mathrm{P}<0.05)$ than the factorial mean (Table 4$)$. The post-weaning slaughter date affected $(\mathrm{P}<0.01)$ the stomach $\mathrm{pH}$; stomach $\mathrm{pH}$ was higher in animals slaughtered $7 \mathrm{~d}$ post-weaning than in animals 
slaughtered $14 \mathrm{~d}$ post-weaning. The digestive system of piglets weaned at $21 \mathrm{~d}$ is not sufficiently adapted to the transition from a milk-based diet to a diet containing plant-derived ingredients. After weaning, there is a reduction in the secretion of acids in the stomach, which increases $\mathrm{pH}$ and reduces the activity of gastric enzymes. Digestibility is thus reduced and there is more substrate for the growth of bacteria (BANWART, 1981). It takes 3-4 wk to reach the $\mathrm{pH}$ level found in the stomachs of adult pigs (CRANWELL; MOUGHAN, 1989).

Table 4. Mean values of $\mathrm{pH}$ of stomach, jejunum, colon and rectum content of piglets as affected by slaughter dates (days after weaning), sources of carbohydrates and use of prebiotic.

\begin{tabular}{cllll}
\hline $\mathrm{pH}$ & Stomach & Jejunum & Colon & Rectum \\
\hline Factorial Mean & $4.1^{\#}$ & $5.7^{\#}$ & $5.9^{\#}$ & $6.6^{\#}$ \\
\hline Weaning Mean & 3.0 & 6.0 & 6.2 & 6.4 \\
\hline Slaughter Dates & & & & 6.6 \\
7 & $4.2 \mathrm{a}^{*}$ & $5.8 \mathrm{a}^{*}$ & 5.8 & 6.6 \\
\hline 14 & $3.9 \mathrm{~b}^{*}$ & $5.6 \mathrm{~b}^{*}$ & 5.9 & $6.7 \mathrm{a}^{*}$ \\
\hline Carbohydrate & & & & $6.5 \mathrm{~b}$ \\
Lactose & 4.1 & 5.7 & 5.9 & 6.6 \\
Maltodextrin & 4.0 & 5.7 & 5.8 & 6.6 \\
\hline Fructooligosaccharides & & & 5.9 & 3.82 \\
With & 4.1 & 5.7 & 5.8 &
\end{tabular}

Means in the same column with different letters are statistically different by $\mathrm{F}$ test $(\mathrm{P}<0.05) ; *$ Means are different of the slaughter at weaning by Dunnett test $(\mathrm{P}<0.05)$. ${ }^{\#}$ Mean of slaughter at weaning is different of the factorial mean by $\mathrm{F}$ test $(\mathrm{P}<0.05)$; $\mathrm{CV}$ : Coefficient of variation.

Source: Elaboration of the authors.

The jejunal $\mathrm{pH}$ was higher $(\mathrm{P}<0.05)$ than the factorial mean (Table 4) in the animals slaughtered at weaning. The jejunal $\mathrm{pH}$ was lower in animals slaughtered at $14 \mathrm{~d}$ post-weaning than in animals slaughtered at $7 \mathrm{~d}$ post-weaning, and both were lower than the jejunal $\mathrm{pH}$ in animals slaughtered at weaning. Jejunal $\mathrm{pH}$ is higher than stomach $\mathrm{pH}$ because the duodenum receives bicarbonatecontaining alkaline secretions from the pancreas, liver, and Brunner glands (present in the duodenal submucosa) that correct the $\mathrm{pH}$ of the gastric contents (YEN, 2001). At 7 and 14 d post-weaning, the jejunal $\mathrm{pH}$ was approximately 6.0, which is a typical value for that segment of the intestine. The $\mathrm{pH}$ of the small intestine should be higher because, unlike the stomach, its epithelium does not have a thick layer of mucosa and because a higher $\mathrm{pH}$ favors the action of pancreatic digestive enzymes (FRANDSON; WILKE; FAILS, 2009). The secretion of bicarbonate in the duodenum is regulated by secretin, a hormone that is released when the duodenum is exposed to acid contents (ARGENZIO, 1996); therefore, a higher $\mathrm{pH}$ of the gastric digesta might have adversely affected the release of secretin and kept the jejunal $\mathrm{pH}$ slightly below the ideal level until $14 \mathrm{~d}$ post-weaning.

None of the treatments had an effect $(\mathrm{P}>0.05)$ on colon $\mathrm{pH}$, with the exception of the value that was observed at weaning, which was higher $(\mathrm{P}<$ 0.05 ) than the factorial mean (Table 4). Montagne et al. (2007) also observed a reduction in colon $\mathrm{pH}$ of piglets until $15 \mathrm{~d}$ post-weaning. This effect might have been caused by the presence of nutrients that were not absorbed in the small intestine, in 
particular, carbohydrates that were utilized as substrate for the microflora. The result was a higher production of volatile fatty acids and the subsequent acidification of the colon contents (BROWN; BAKER; BARKER, 2007).

The rectal $\mathrm{pH}$ of the animals that were slaughtered at weaning was lower $(\mathrm{P}<0.05)$ than the factorial mean (Table 4). The rectal $\mathrm{pH}$ was affected by the source of carbohydrates $(\mathrm{P}<0.01)$; the rectum of piglets that were fed a diet containing lactose exhibited a higher $\mathrm{pH}$. The fermentation of some carbohydrates is slower in the large intestine and, when they reach the distal region of the colon, an increase in short-chain fatty acid production and a reduction in $\mathrm{pH}$ are observed (GLITS $\varnothing$ et al., 1998). The monosaccharides that are present in the colon and derived from the digestion of maltodextrin (NEMCOVÁ et al., 2007) might have been utilized as a substrate for bacteria, resulting in the production of short-chain fatty acids that reduce the $\mathrm{pH}$ of the rectum. The rectal $\mathrm{pH}$ in piglets that were slaughtered at weaning was not different from that in piglets that were fed with maltodextrin. The absence of an effect $(\mathrm{P}>0.05)$ from the use of FOSs on the $\mathrm{pH}$ of the organs that were evaluated (Table 4) confirms the results obtained by Shim, Williams and Verstegen (2005), who did not observe an effect of using $0.25 \%$ FOSs in the diet on the $\mathrm{pH}$ values of the gastrointestinal tract; however, when they used 3.0\% FOSs in the diet, they did observe a reduction in the proximal colon $\mathrm{pH}$, because there was higher short-chain fatty acid production (above the absorption capacity of the large intestine).

The interactions did not affect $(P>0.05)$ the relative weight of the organs (Table 5). The factorial mean was higher than the value for animals slaughtered at weaning for all organs evaluated. The slaughter date had an effect $(\mathrm{P}<0.01)$ on all organs; values observed in animals slaughtered at
$14 \mathrm{~d}$ post-weaning were higher than those observed in animals slaughtered at $7 \mathrm{~d}$ post-weaning, and both were higher than values at weaning.

Sarkar, Lodge and Friend (1977) found that the piglets' body tissues exhibited hyperplasia (an increased number of cells) up to $50 \mathrm{~d}$ of age; however, organs grow at different rates, depending on the degree of stimulation. Because of rapid growth and high energy requirements, the pig's body is particularly sensitive to the physical and chemical environmental conditions in the first stages of development (FRIEDMAN et al., 1994); therefore, after weaning, the gastrointestinal tract is stimulated by physical and chemical changes in the diet, which might explain the higher weight-gain rate of these organs compared to the body weightgain rate. This allows for a better use of the diet's nutrients and increased animal growth.

The interactions did not affect $(\mathrm{P}>0.05)$ the specific and total maltase and amylase activities and the total lactase activity (Table 6). The factorial mean was significantly different from all enzyme activity values at weaning, with the exception of the specific maltase activity. Values at weaning were lower for total activity and higher for specific lactase and amylase activity. The specific maltase activity was not affected $(\mathrm{P}>0.05)$ by any of the treatments.

Kidder and Manners (1980) compared piglets weaned at $21 \mathrm{~d}$ and suckling piglets of the same age. They observed a higher specific maltase activity in the 5th week of life of the weaned animals, which is explained by the intake of feed. The effect of diet observed by these authors was mostly because they compared a solid diet to a diet of maternal milk, whereas the diets in the present study were based on corn, which is rich in starch and also requires the action of maltase in the digestive process. 
Table 5. Relative organ weight (\%) in relation to live weight of piglets as affected by slaughter dates (days after weaning), sources of carbohydrates and use of prebiotic.

\begin{tabular}{clllll}
\hline Relative weight & Stomach & Pancreas & Small intestine & Caecum & Large intestine \\
\hline Factorial Mean & $0.80^{*}$ & $0.25^{\#}$ & $4.15^{*}$ & $0.19^{\#}$ & $1.33^{\#}$ \\
\hline Weaning Mean & 0.48 & 0.12 & 2.41 & 0.13 & 0.69 \\
\hline Slaughter Dates & & & & & \\
7 & $0.76 \mathrm{~b}^{*}$ & $0.23 \mathrm{~b}^{*}$ & $3.77 \mathrm{~b}^{*}$ & $0.18 \mathrm{~b}^{*}$ & $1.20 \mathrm{~b}^{*}$ \\
14 & $0.83 \mathrm{a}^{*}$ & $0.26 \mathrm{a}^{*}$ & $4.52 \mathrm{a}^{*}$ & $0.20 \mathrm{a}^{*}$ & $1.45 \mathrm{a}^{*}$ \\
\hline Carbohydrate & & & & \\
$\quad$ Lactose & 0.80 & 0.24 & 4.23 & 0.19 & 1.30 \\
Maltodextrin & 0.79 & 0.24 & 4.06 & 0.19 & 1.35 \\
\hline Fructooligosaccharides & & & & \\
With & 0.79 & 0.24 & 4.13 & 0.19 & 1.30 \\
Without & 0.80 & 0.25 & 4.16 & 0.19 & 1.35 \\
\hline CV (\%) & 11.51 & 15.25 & 10.86 & 16.52 & 10.81 \\
\hline
\end{tabular}

Means in the same column with different letters are statistically different by $\mathrm{F}$ test $(\mathrm{P}<0.05)$; * Means are different of the slaughter at weaning by Dunnett test $(\mathrm{P}<0.05)$. " Mean of slaughter at weaning is different of the factorial mean by $\mathrm{F}$ test $(\mathrm{P}<0.05)$; $\mathrm{CV}$ : Coefficient of variation.

Source: Elaboration of the authors.

Table 6. Specific (S) and total (T) activity of maltase (M), lactase (L) and amylase (A) of piglets as affected by slaughter dates (days after weaning), sources of carbohydrates and use of prebiotic.

\begin{tabular}{cllllll}
\hline \multirow{2}{*}{ Enzymatic Activity } & SM & TM & SL & TL & SA & TA \\
\cline { 2 - 7 } & $\mathrm{u} / \mathrm{g}$ mucosa & $\begin{array}{l}\mathrm{u} / \mathrm{g} \\
\text { live weight }\end{array}$ & $\begin{array}{l}\mathrm{u} / \mathrm{g} \\
\text { mucosa }\end{array}$ & $\begin{array}{l}\mathrm{u} / \mathrm{g} \\
\text { live weight }\end{array}$ & $\mathrm{u} / \mathrm{mg}$ tissue & $\begin{array}{l}\mathrm{u} / \mathrm{g} \\
\text { live weight }\end{array}$ \\
\hline Factorial Mean & 1.18 & $4.90^{\#}$ & $1.15^{\#}$ & $4.70^{\#}$ & $19.25^{\#}$ & $4784.77^{\#}$ \\
\hline Weaning Mean & 1.16 & 2.80 & 1.26 & 3.03 & 23.38 & 2798.37 \\
\hline Slaughter Dates & & & & & & \\
7 & 1.19 & $4.47 \mathrm{~b}^{*}$ & 1.15 & $4.24 \mathrm{~b}^{*}$ & $15.79 \mathrm{~b}^{*}$ & $3603.11 \mathrm{~b}$ \\
14 & 1.18 & $5.33 \mathrm{a}^{*}$ & 1.14 & $5.16 \mathrm{a}^{*}$ & $22.72 \mathrm{a}$ & $5966.43 \mathrm{a}^{*}$ \\
\hline Carbohydrate & & & & & & \\
Lactose & 1.19 & 5.02 & 1.16 & $4.89 \mathrm{a}^{*}$ & 18.50 & 4662.79 \\
Maltodextrin & 1.18 & 4.78 & 1.14 & $4.51 \mathrm{~b}^{*}$ & 20.01 & 4906.76 \\
\hline Fructooligosaccharides & & & & & & \\
With & 1.18 & 4.87 & 1.15 & 4.62 & 20.38 & 4916.33 \\
Without & 1.18 & 4.93 & 1.15 & 4.78 & 18.12 & 4653.22 \\
\hline CV (\%) & 7.06 & 13.25 & 7.56 & 15.03 & 21.02 & 28.06
\end{tabular}

Means in the same column with different letters are statistically different by $\mathrm{F}$ test $(\mathrm{P}<0.05)$; * Means are different of the slaughter at weaning by Dunnett test $(\mathrm{P}<0.05)$. ${ }^{\#}$ Mean of slaughter at weaning is different of the factorial mean by $\mathrm{F}$ test $(\mathrm{P}<0.05)$; $\mathrm{CV}$ : Coefficient of variation.

Source: Elaboration of the authors.

The absence of an effect of the source of carbohydrates on the specific and total maltase activities was probably because the amount of maltodextrin that was added to the pre-starter I feed $(12 \%)$ was not sufficient to further increase the intestinal maltase activity.
Kidder and Manners (1980) did not observe any differences in maltase activity between piglets weaned at $21 \mathrm{~d}$ and suckling piglets of the same age in the 8th week of life. They concluded that age has a more significant effect than that by diet on the activity of enzymes. Thymann et al. (2009) observed 
that the specific maltase activity in preterm piglets was higher when lactose was used in enteric diets than when maltodextrin was used, possibly because lactose is a better inducer of piglet development and thus increases maltase activity, even if it is not its specific substrate.

According to Quezada-Calvillo et al. (2007), maltose and maltodextrin are digested by a set of 4 enzymes called maltases, which are divided into the sucrase-isomaltase and maltase-glucoamylase complexes. These are responsible for approximately 70 and $20 \%$ of the hydrolysis of those carbohydrates, respectively. Thus, the sucrase-isomaltase activity would be a more sensitive variable by which to detect the modulating effect of maltodextrin. Thymann et al. (2009) observed higher sucrase activity in piglets that were fed enteric maltodextrin-containing diets than in piglets that were fed lactose-containing diets.

The total maltase and lactase activities were higher $(\mathrm{P}<0.01)$ in animals slaughtered at $14 \mathrm{~d}$ post-weaning than in animals slaughtered at $7 \mathrm{~d}$ post-weaning (Table 6), and both were higher than values at weaning. These results are a result of the increase in the relative weight of the small intestine with age (Table 5), but the increase in feed intake in the second week post-weaning relative to the first week post-weaning should also be noted.

With regard to the sources of carbohydrates, the lactose-based diet resulted in higher total lactase activity $(\mathrm{P}<0.05)$, which was expected because lactose in the diet is the substrate for the action of lactase.

The interaction between the source of carbohydrates and FOSs $(\mathrm{P}<0.05)$ affected specific lactase activity (Table 7). No difference was observed $(\mathrm{P}>0.05)$ between the sources of carbohydrates when FOSs were not used; however, in the presence of the prebiotic, the specific lactase activity was higher $(\mathrm{P}<0.05)$ in animals that were fed with lactose. Because the interaction was significant, we compared the mean lactase activity in animals slaughtered at weaning to each individual mean by using the Dunnett test. Only with the use of lactose in the presence of FOSs was the specific lactase activity similar to that observed at weaning.

Table 7. Unfolding of interaction of sources of carbohydrates and use of prebiotic to the specific activity of lactase (u/g mucosa) of piglets.

\begin{tabular}{ccc}
\hline \multirow{2}{*}{ Carbohydrate } & \multicolumn{3}{c}{ Fructooligosaccharides } \\
\cline { 2 - 3 } & With & Without \\
\hline Lactose & $1.178 \mathrm{a}$ & $1.133^{*}$ \\
Maltodextrin & $1.113 \mathrm{~b}^{*}$ & $1.165^{*}$ \\
\hline Weaning & \multicolumn{3}{c}{1.260} \\
\hline LSD Dunnett & 0.084 \\
\hline
\end{tabular}

Means in the same column with different letters are statistically different by $\mathrm{F}$ test $(\mathrm{P}<0.05)$; Means are different of the slaughter at weaning by Dunnett test $(\mathrm{P}<0.05)$; LSD: least significant difference.

Source: Elaboration of the authors.

Lactase, as other disaccharidases, is produced in the microvilli of enterocytes. This is why damage to the intestinal mucosa induces shortening of villi and reduces lactase production, where the latter resumes only after cellular recovery (HEUBI et al., 2000). According to Roediger (1982), prebiotics, once fermented, generate short-chain fatty acids that are utilized in the metabolism of enterocytes and induce villi growth. Budiño et al. (2005) observed an increase in villi density with the use of FOSs in weaned piglets; therefore, FOSs might have provided better conditions for enzyme synthesis. This and the presence of lactose resulted in a higher specific lactase activity in animals fed a diet containing lactose and FOSs (Table 7). 
The specific and total amylase activities were affected $(\mathrm{P}<0.01)$ only by the age at slaughter. At $14 \mathrm{~d}$ post-weaning, these activities were higher than those observed at $7 \mathrm{~d}$ post-weaning (Table 6). The specific amylase activity was lower at $7 \mathrm{~d}$ postweaning $(\mathrm{P}<0.05)$ than at weaning, whereas at 14 d post-weaning, it did not differ from that observed in animals that were slaughtered at weaning. Similar results were obtained by Jensen, Jensen and Jakobsen (1997), who observed a reduction in specific amylase activity at $7 \mathrm{~d}$ post-weaning and an increase at $14 \mathrm{~d}$ post-weaning.

The reduction in specific amylase activity at $7 \mathrm{~d}$ post-weaning (Table 6) demonstrates that it was high at the time of weaning; according to Lindemann et al. (1986), feeding piglets during the lactating phase induces the production of amylase by the pancreas. Moreover, the reduction in specific amylase activity after weaning was the result of the drastic reduction in feed intake, in particular, in the first days after weaning, which was caused by stress from separation from the sow, transportation, changes in diet, and environment. This effect caused by weaning was described by Owsley, Orr Júnior and Tribble (1986), who observed that on the day following weaning, there was a sharp decrease in amylase activity in the intestine; however, at $4 \mathrm{~d}$ post-weaning, the decrease in activity was observed in the pancreas. This demonstrates that low feed intake reduces the secretion of enzymes by the pancreas into the duodenum; however, if the low intake continues, then a reduction in the synthesis of enzymes in the pancreas is observed, including that of its precursors (OWSLEY; ORR JÚNIOR; TRIBBLE, 1986).

The total amylase activity did not vary $(\mathrm{P}>0.05)$ between the day of weaning and $7 \mathrm{~d}$ post-weaning; however, total amylase activity was higher at 14 d post-weaning than in animals slaughtered at weaning, which shows that total amylase activity was more affected by the relative weight of the pancreas than by specific amylase activity.
The sources of variation did not affect the population of Lactobacillus, with the exception of the factorial mean, which was lower than the value for animals slaughtered at weaning (Table $8)$. This result corroborates the results obtained by Konstantinov et al. (2006), who observed that the populations of L. acidophilus, L. sobrius, and $L$. reuteri remained high from birth until weaning, and that there was a significant reduction after weaning. This result might be attributed to a higher intake of lactose by suckling piglets at the end of the lactation period, when normal intake is approximately $1 \mathrm{~L}$ milk, which, according to Klobasa, Werhahn and Butler (1987), contains $18.7 \%$ dry matter, of which $31 \%$ is lactose. The decrease in the population of Lactobacillus after weaning might also be caused by increased animal age and stress factors, such as mixing with other piglets, lower feed intake than required, and transportation (SGHIR; ANTONOPOULOS; MACKIE, 1998).

We expected the use of lactose in the piglets' diet to increase the population of Lactobacillus because lactose is a specific substrate for Lactobacillus (POLLMANN; DANIELSON; PEO, 1980). Pierce et al. (2007) observed that weaned piglets fed a diet containing $21.5 \%$ lactose had a higher number of Lactobacillus than piglets fed a diet containing $12.5 \%$ lactose; the same relationship was observed when a diet containing 33.0\% lactose was compared to a diet containing 15.0\% lactose (PIERCE et al., 2006). Both studies also found a higher concentration of total volatile fatty acids in the feces (PIERCE et al., 2007), colon, and cecum (PIERCE et al., 2006). The absence of an effect of the presence of lactose in the diet on the Lactobacillus population of the cecum that was observed in the present experiment might be because less lactose (12\%) was used in the feed compared to that used in the study by Pierce et al. (2006; 2007). Hence, the lactose was completely digested in the small intestine and there was no substrate left for fermentation by Lactobacilli in the cecum. 
Table 8. Count of colony forming units $(\log 10 / \mathrm{g})$ in caecum of piglets as affected by slaughter dates (days after weaning), sources of carbohydrates and use of prebiotic.

\begin{tabular}{clll}
\hline Microbial counts & Lactobacillus & Total coliform & E. coli \\
\hline Factorial Mean & $8.46^{\#}$ & $5.31^{\#}$ & $5.22^{\#}$ \\
\hline Weaning Mean & 9.44 & 7.39 & 7.36 \\
\hline Slaughter Dates & & & 5.33 \\
7 & 8.45 & 5.38 & 5.11 \\
14 & 8.47 & 5.24 & 5.28 \\
Carbohydrate & & & 5.16 \\
Lactose & 8.36 & 5.35 & \\
Maltodextrin & 8.56 & 5.27 & 5.23 \\
Fructooligosaccharides & & & 5.20 \\
With & 8.53 & 5.37 & 11.34 \\
Without & 8.40 & 5.25 & 11.69 \\
\hline CV $(\%)$ & 5.30 &
\end{tabular}

Means in the same column with different letters are statistically different by $\mathrm{F}$ test $(\mathrm{P}<0.05)$; ${ }^{*}$ Means are different of the slaughter at weaning by Dunnett test $(\mathrm{P}<0.05) .{ }^{*}$ Mean of slaughter at weaning is different of the factorial mean by $\mathrm{F}$ test $(\mathrm{P}<0.05)$; $\mathrm{CV}$ : Coefficient of variation.

Source: Elaboration of the authors.

Total coliform and E. coli populations were higher than the factorial mean on the day of weaning (Table 8). This result might be related to the addition of zinc oxide to the pre-starter feeds, which reduces the populations of pathogenic microorganisms and the occurrence of diarrhea.

The interaction between age at slaughter and source of carbohydrates was significant $(\mathrm{P}<0.05)$ for these 2 variables (Table 9). With the use of maltodextrin and at $14 \mathrm{~d}$ post-weaning, the total coliform and E. coli populations were lower for both the carbohydrate and age factors, which suggests that maltodextrin has a prebiotic effect. Bomba et al. (2002) supplied L. paracasei alone and did not observe an inhibitory effect on the adhesion of $E$. coli to the jejunal mucosa in gnotobiotic piglets, whereas the supply of a combination of L. paracasei and maltodextrin reduced the number of $E$. coli in the jejunal mucosa. A similar result was obtained by Nemcová et al. (2007) when piglets aged 7-d that were administered L. plantarum + maltodextrin + FOSs and L. plantarum + maltodextrin exhibited a decrease in the population of $E$. coli in the jejunum compared to those that were administered $L$. plantarum alone and L. plantarum + FOSs.

In the present experiment, maltodextrin might not have been completely digested in the small intestine and the undigested fraction might have been utilized as a substrate for beneficial bacteria in the cecum, thus increasing the inhibitory effect on total coliform and E. coli populations (Table 9). The possible prebiotic effect of maltodextrin occurred at only $14 \mathrm{~d}$ post-weaning, probably because of the low intake of feed in the first $7 \mathrm{~d}$ after weaning. 
Table 9. Unfolding of interaction of slaughter dates and sources of carbohydrates of count of colony forming units (log $10 / \mathrm{g}$ ) of total coliform and E. coli in caecum of piglets.

\begin{tabular}{ccc}
\hline & \multicolumn{2}{c}{ Total coliform } \\
\hline \multirow{2}{*}{ Slaughter Dates } & \multicolumn{2}{c}{ Carbohydrate } \\
\cline { 2 - 3 } & Lactose & Maltodextrin \\
\hline 7 & $5.24^{*}$ & $5.52 \mathrm{a}^{*}$ \\
14 & $5.47 \mathrm{~A}^{*}$ & $5.01 \mathrm{bB}^{*}$ \\
\hline Weaning & \multicolumn{2}{c}{7.39} \\
\hline LSD Dunnett & E. coli & 0.62 \\
\hline 7 & $5.18^{*}$ & $5.47 \mathrm{a}^{*}$ \\
14 & $5.38 \mathrm{~A}^{*}$ & $4.85 \mathrm{bB}^{*}$ \\
\hline Weaning & \multicolumn{3}{|}{} \\
\hline LSD Dunnett & \multicolumn{3}{c}{0.59} \\
\hline
\end{tabular}

Means with different capital letters in the same row and lower-case letters in the same column are statistically different by $\mathrm{F}$ test $(\mathrm{P}$ $<0.05)$; * Means are different of the slaughter at weaning by Dunnett test $(\mathrm{P}<0.05)$; LSD: least significant difference.

Source: Elaboration of the authors.

\section{Conclusions}

In the initial phase, maltodextrin does not compromise the feed performance and can be used to replace lactose; however, it reduces the intake of the pre-starter I feed.

Maltodextrin has a prebiotic effect because it reduces the population of total coliform and E. coli in the cecum and the $\mathrm{pH}$ of the rectal contents.

The use of FOSs is not justified, regardless of whether lactose or maltodextrin is added to the feed.

\section{Acknowledgments}

The present work was funded by the Fundação de Amparo à Pesquisa do Estado de São Paulo (grant number: 11/09115-0).

\section{Ethics Committee}

The experiment was conducted according to the Ethical Principles for Animal Experimentation and was approved by the Ethics Committee on Animal Use (Protocol 30/2011-CEUA) of the Faculty of Veterinary Medicine and Zootechnics of the Universidade Estadual Paulista.

\section{References}

ASSOCIATION OF OFFICIAL ANALYTICAL CHEMISTS - AOAC. Method 998.08. In: Official methods of analysis of AOAC international, 2000, p. 3940.

ARGENZIO, R. A. Funções secretórias do trato gastrintestinal. In: SWENSON, M. J.; REECE, W. O. (Ed.). Dukes - fisiologia dos animais domésticos. 11. ed. Rio de Janeiro: Guanabara Koogan, 1996. p. 319-329.

AUGUSTO, R. M. N.; BERTO, D. A.; LO TIERZO, V.; MELLO, G.; HAUPTLI, L.; LUCCHESI, L. Maltodextrina em rações de leitões desmamados com diferentes pesos: desempenho e morfometria intestinal. Acta Scientiarum: Animal Sciences, Maringá, v. 33, n. 1, p. 41-46, 2011.

BANWART, G. J. Basic food microbiology. Westport: AVI Publishing, 1981. 519 p.

BERROCOSO, J. D.; SERRANO, M. P.; CÁMARA, L.; REBOLLAR, P. G.; MATEOS, G. G. Influence of diet complexity on productive performance and nutrient digestibility of weanling pigs. Animal Feed Science and Technology, Amsterdam, v. 171, n. 2-4, p. 214-222, 2012.

BERTOL, T. M.; SANTOS FILHO, J. I.; LUDKE, J. V. Níveis de suplementação de lactose na dieta de leitões desmamados. Revista Brasileira de Zootecnia, Viçosa, v. 29, n. 5, p. 1387-1393, 2000.

BHANDARI, B. R.; DATTA, N.; HOWES, T. Problems associated with spray drying of sugar-rice foods. Drying Technology, Philadelphia, v. 15, n. 2, p. 671-684, 1997. 
BOMBA, A.; NEMCOVÁ, R.; GANCARCÍKOVÁ, S.; HERICH, R.; GUBA, P.; MUDRONOVÁ, D. Improvement of the probiotic effect of micro-organisms by their combination with maltodextrins, fructooligosaccharides and polyunsaturated fatty acids. British Journal of Nutrition, London, v. 88, p. 95-99, 2002. Supplement 1.

BROWN, C.; BAKER, D. C.; BARKER, I. K. Alimentary System. In: MAXIE, M. G. (Ed.). Pathology of domestic animals. 5. ed. Philadelphia: Saunders Elsevier, 2007. p. 3-296.

BUDIÑO, F. E. L.; THOMAZ, M. C.; KRONKA, R. N.; NAKAGHI, L. S. O.; TUCCI, F. M.; FRAGA, A. L.; SCANDOLERA, A. J.; HUAYNATE, R. A. R. Effect of probiotic and prebiotic inclusion in weaned piglet diets on structure and ultra-structure of small intestine. Brazilian Archives of Biology and Technology, Curitiba, v. 48, n. 6, p. 921-929, 2005.

BUDIÑO, F. E. L.; CASTRO JÚNIOR, F. G.; OTSUK, I. P. Adição de frutoligossacarídeo em dietas para leitões desmamados: desempenho, incidência de diarréia e metabolismo. Revista Brasileira de Zootecnia, Viçosa, v. 39, n. 10, p. 2187-2193, 2010.

CHOTIKATUM, S.; KRAMOMTHONG, I.; ANGKANAPORN, K. Effects of medium chain fatty acids, organic acids and fructo-oligosaccharide on cecal Salmonella Enteritidis colonization and intestinal parameters of broilers. The Thai Journal of Veterinary Medicine, Bangkok, v. 39, n. 3, p. 245-258, 2009.

CLOUARD, C.; CHATAIGNIER, M.; MEUNIERSALAUN, M. C.; VAL-LAILLET, D. Flavour preference acquired via a beverage-induced conditioning and its transposition to solid food: Sucrose but not maltodextrin or saccharin induced significant flavour preferences in pigs. Applied Animal Behaviour Science, Amsterdam, v. 136, n. 1, p. 26-36, 2012.

CRANWELL, P. D.; MOUGHAN, P. J. Biological limitations imposed by the digestive system to the growth performance of weaned pigs. In: BARNETT, J. L.; HENNESSY, D. P. (Ed.). Manipulating pig production II. Werribee: Australasian Pig Science Association, 1989. p. $140-165$.

DAHLQUIST, A. Method for assay of intestinal disaccharidases. Analytical Biochemistry, New York, v. 7, n. 1, p. 447-454, 1964.

DOWNES, F. P.; ITO, K. (Ed.). Compendium of methods for the microbiological examination of foods. 4. ed. Washington: APHA, 2001. $676 \mathrm{p}$.

FRANDSON, R. D.; WILKE, W. L.; FAILS, A. D. Anatomy and physiology of farm animals. 7. ed. Ames:
Wiley-Blackwell, 2009. 512 p.

FRIEDMAN, L.; GAINES, D. W.; NEWELL, R. F.; SAGER, A. O.; MATTHEWS R. N.; BRAUNBERG, R. C. Body and organ growth of the developing HormelHanford strain of male miniature swine. Laboratory Animals, London, v. 28, n. 4, p. 376-379, 1994.

GLITSØ, L. V.; BRUNSGAARD, G.; HØJSGAARD, S.; SANDSTRÖM, B.; BACH KNUDSEN, K. E. Intestinal degradation in pigs of rye dietary fibre with different structural characteristics. British Journal of Nutrition, London, v. 80, n. 5, p. 457-468, 1998.

HEUBI, J.; KARASOV, R.; REISINGER, K.; BLATTER, M.; ROSENBERG, L.; VANDERHOOF, J.; DARDEN, P. M.; SAFIER, J.; MARTIN, T.; EULER, A. R. Randomized multicenter trial documenting the efficacy and safety of a lactose-free and a lactose-containing formula for term infants. Journal of the American Dietetic Association, Chicago, v. 100, n. 2, p. 212-217, 2000.

JAIN, N. C. Essentials of veterinary hematology. Philadelphia: Lea \& Febiger, 1993. 417 p.

JENSEN, M. S.; JENSEN, S. K.; JAKOBSEN, K. Development of digestive enzymes in pigs with emphasis on lipolytic activity in the stomach and pancreas. Journal of Animal Science, Champaign, v. 75, n. 2, p. 437-445, 1997.

KIDDER, D. E.; MANNERS, M. J. The level and distribution of carbohydrases in the small intestine mucosa of pigs from 3 weeks of age to maturity. British Journal of Nutrition, London, v. 43, n. 1, p. 141-153, 1980.

KLOBASA, F.; WERHAHN, E.; BUTLER, J. E. Composition of sow milk during lactation. Journal of Animal Science, Champaign, v. 64, n. 5, p. 1458-1466, 1987.

KONSTANTINOV, S. R.; AWATI, A. A.; WILLIAMS, B. A.; MILLER, B. G.; JONES, P.; STOKES, C. R.; AKKERMANS, A. D. L.; SMIDT, H.; DE VOS, W. M. Post-natal development of the porcine microbiota composition and activities. Environmental Microbiology, Oxford, v. 8, n. 7, p. 1191-1199, 2006.

LANGENDIJK, P.; BOLHUIS, J. E.; LAURENSSEN, B. F. A. Effects of pre- and postnatal exposure to garlic and aniseed flavour on pre- and post-weaning feed intake in pigs. Livestock Science, Amsterdam, v. 108, n. 1-3, p. 284-287, 2007.

LINDEMANN, M. D.; CORNELIUS, S. G.; EL KANDELGY, S. M.; MOSER R. L.; PETTIGREW, J. E. Effect of age, weaning and diet on digestive enzyme levels in the piglet. Journal of Animal Science, Champaign, v. 62, n. 5, p. 1298-1307, 1986. 
MAHAN, D. C.; NEWTON, E. A. Evaluation of feed grains with dried skim milk and added carbohydrate sources on weanling pig performance. Journal of Animal Science, Champaign, v. 71, n. 12, p. 3376-3382, 1993.

MONTAGNE, L.; BOUDRY, G.; FAVIER, C.; HUËROULURON, I. L.; LALLÈS, J. P.; SÈVE, B. Main intestinal markers associated with the changes in gut architecture and function in piglets after weaning. British Journal of Nutrition, London, v. 97, n. 1, p. 45-57, 2007.

NEMCOVÁ, R.; BOMBA, A.; GANCARČÍKOVÁ, S.; HERICH, R.; GUBA, P. Study of the effect of Lactobacillus paracasei and fructooligosaccharides on the faecal microflora in weanling piglets. Berliner und Munchener Tierarztliche Wochenschrift, Berlin, v. 112, n. 6-7, p. 225-228, 1999.

NEMCOVÁ, R.; BOMBA, A.; GANCARCÍKOVÁ, S.; REIFFOVÁ, K.; GUBA, P.; KOSKOVA, J.; JONECOVA, Z.; SCIRANKOVA, L.; BUGARSKY, A. Effects of the administration of Lactobacilli, maltodextrins and fructooligosaccharides upon the adhesion of $E$. coli O8:K88 to the intestinal mucosa and organic acid levels in the gut contents of piglets. Veterinary Research Communications, Dordrecht, v. 31, n. 7, p. 791-800, 2007.

O'DOHERTY, J. V.; NOLAN, C. S.; MCCARTHY, P. C. Interaction between lactose levels and antimicrobial growth promoters on growth performance of weanling pigs. Journal of the Science of Food and Agriculture, Oxford, v. 85, n. 3, p. 371-380, 2005.

OLIVER, W. T.; MATHEWS, S. A.; PHILLIPS, O.; JONES, E. E.; ODLE, J.; HARREL, R. J. Efficacy of partially hydrolyzed corn syrup solids as a replacement for lactose in manufactured liquid diets for neonatal pigs. Journal of Animal Science, Champaign, v. 80, n. 1, p. 143-153, 2002.

OOSTINDJER, M.; BOLHUIS, J. E.; VAN DEN BRAND, H.; ROURA, E.; KEMP, B. Prenatal flavor exposure affects growth, health and behavior of newly weaned piglets. Physiology and Behavior, Elmsford, v. 99 , n. 5, p. 579-586, 2010.

OWSLEY, W. F.; ORR JÚNIOR, D. E.; TRIBBLE, L. F. Effects of age and diet on the development of the pancreas and the synthesis and secretion of pancreatic enzymes in the young pig. Journal of Animal Science, Champaign, v. 63, n. 2, p. 497-504, 1986.

PIERCE, K. M.; CALLAN, J. J.; MCCARTHY, P.; O'DOHERTY, J. V. The interaction between lactose level and crude protein concentration on piglet postweaning performance, nitrogen metabolism, selected faecal microbial populations and faecal volatile fatty acid concentrations. Animal Feed Science and Technology, Amsterdam, v. 132, n. 3-4, p. 267-282, 2007.

PIERCE, K. M.; SWEENEY, T.; BROPHY, P. O.; CALLAN, J. J.; FITZPATRICK, E.; MCCARTHY, P.; O'DOHERTY, J. V. The effect of lactose and inulin on intestinal morphology, selected microbial populations and volatile fatty acid concentrations in the gastro-intestinal tract of the weaned pig. Animal Science, Penicuik, v. 82, n. 3, p. 311-318, 2006.

POLLMANN, D. S.; DANIELSON, D. M.; PEO, E. R. Effect of Lactobacillus acidophilus on starter pigs fed a diet supplemented with lactose. Journal of Animal Science, Champaign, v. 51, n. 3, p. 638-644, 1980.

QUEZADA-CALVILLO, R.; ROBAYO-TORRES, C. C.; AO, Z.; HAMAKER, B. R.; QUARONI, A.; BRAYER, G. D.; STERCHI, E. E.; BAKER, S. S.; NICHOLS, B. L. Luminal substrate "brake" on mucosal maltase-glucoamylase activity regulates total rate of starch digestion to glucose. Journal of Pediatric Gastroenterology and Nutrition, New York, v. 45, n. 1, p. 32-43, 2007.

ROBERFROID, M. B. Inulin-type fructans: functional food ingredients. The Journal of Nutrition, Bethesda, v. 137, n. 11, p. 2493-2502, 2007.

ROBERFROID, M.; GIBSON, G. R.; HOYLES, L.; MCCARTNEY, A. L.; RASTALL, R.; ROWLAND, I.; WOLVERS, D.; WATZL, B.; SZAJEWSKA, H.; STAHL, B.; GUARNER, F.; RESPONDEK, F.; WHELAN, K.; COXAM, V.; DAVICCO, M. J.; LÉOTOING, L.; WITTRANT, Y.; DELZENNE, N. M.; CANI, P. D.; NEYRINCK, A. M.; MEHEUST, A. Prebiotic effects: metabolic and health benefits. British Journal of Nutrition, London, v. 104, p. 1-63, 2010. Supplement 2.

ROEDIGER, W. E. Utilization of nutrients by isolated epithelial cells of the rat colon. Gastroenterology, Baltimore, v. 83, n. 2, p. 424-429, 1982.

ROSTAGNO, H. S.; ALBINO, L. F. T.; DONZELE, J. L.; GOMES, P. C.; OLIVEIRA, R. F.; LOPES, D. C.; FERREIRA, A. S.; BARRETO, S. L. T. Composição de alimentos e exigências nutricionais. Tabelas brasileiras para aves e suínos. 2. ed. Viçosa: Editora UFV, 2005. $186 \mathrm{p}$.

SISTEMA PARAANÁLISES ESTATÍSTICAS - SAEG. Versão 9.1. Viçosa: Fundação Arthur Bernardes, 2009.

SARGEANT, H. R.; SHAW, M. A.; ABUOUN, M.; COLLINS, J. W.; WOODWARD, M. J.; LA RAGIONE, R. M.; MILLER, H. M. The metabolic impact of zinc oxide on porcine intestinal cells and enterotoxigenic Escherichia coli K88. Livestock Science, Amsterdam, v. 133, n. 1-3, p. 45-48, 2010. 
SARKAR, N. K.; LODGE, G. A.; FRIEND, D. W. Hyperplasic and hypertrophic growth in organs and tissues of the neonatal pig. Journal of Animal Science, Champaign, v. 45, n. 4, p. 722-728, 1977.

SGHIR, A.; ANTONOPOULOS, D.; MACKIE, R. I. Design and evaluation of a Lactobacillus group-specific ribosomal RNA-targeted hybridisation probe and its application to the study of intestinal microecology in pigs. Systematic and Applied Microbiology, Stuttgart, v. 21, n. 2, p. 291-296, 1998.

SHIM, S. B.; WILLIAMS, I. H.; VERSTEGEN, M. W. A. Effects of dietary fructo-oligosaccharide on villous height and disaccharidase activity of the small intestine, $\mathrm{pH}$, VFA and ammonia concentrations in the large intestine of weaned pigs. Acta Agriculturae Scandinavica - Animal Science, Stockholm, v. 55, n. 2/3, p. 91-97, 2005.

SILVA, A. M. R.; BERTO, D. A.; LIMA, G. J. M. M.; WECHSLER, F. S.; PADILHA, P. M.; CASTRO, V. S. Valor nutricional e viabilidade econômica de rações suplementadas com maltodextrina e acidificante para leitões desmamados. Revista Brasileira de Zootecnia, Viçosa, v. 37, n. 2, p. 286-295, 2008.

SOARES, J. L.; DONZELE, J. L.; OLIVEIRA, R. F. M.; FERREIRA, A. S.; FERREIRA, C. L. L. F.; HANNAS, M. I.; APOLÔNIO, L. R. Soja integral processada (Fermentada e Extrusada) e farelo de soja em substituição ao leite em pó em dieta de leitões desmamados aos 14 dias de idade. Revista Brasileira de Zootecnia, Viçosa, v. 29, n. 4, p. 1153-1161, 2000.
THYMANN, T.; MØLLER, H. K.; STOLL, B.; STØY, A. C. F.; BUDDINGTON, R. K.; BERING, S. B.; JENSEN, B. B.; OLUTOYE, O. O.; SIGGERS, R. H.; MØLBAK, L.; SANGILD, P. T.; BURRIN, D. G. Carbohydrate maldigestion induces necrotizing enterocolitis in preterm pigs. American Journal of Physiology - Gastrintestinal and Liver Physiology, Bethesda, v. 297, n. 6, p. 11151125, 2009.

VISENTINI, P. R. S.; BERTO, D. A.; HAUPTLI, L.; PINTO, J. P. A. N.; TRINDADE NETO, M. A.; WECHSLER, F. S.; SCHERER, M. R. Adição de frutooligosacarídeos e olaquindox à dieta sobre o desempenho, microbiota intestinal e parâmetros sanguíneos de leitões desmamados. Veterinária e Zootecnia, São Paulo, v. 15, n. 3, p. 570-576, 2008.

YEN, J. T. Anatomy of the digestive system and nutritional physiology. In: LEWIS, A. J.; SOUTHERN, L. L. (Ed.). Swine nutrition. 2. ed. New York: CRC Press, 2001. p. 31-64. 
